\title{
Trends in Development of Corporate Organizational and Managerial Innovations in Russia and the Principles of Lean Production
}

\author{
Svetlana Valentinovna ludina \\ Mukhabbat Sharifovna Garifullina \\ Nataliya Vladimirovna Serikova
}

Kazan National Research Technical University named after A.N. Tupolev - KAl, Almetyevsk Branch

Doi:10.5901/mjss.2015.v6n3p492

\section{Abstract}

The great interest in the concepts, principles, and tools of lean production is caused not only and not so much by the "fashion" for the organizational and managerial innovations, as by the need to find new reserves to improve production efficiency (in particular, in the oil extraction industry). In Russian (including Soviet) theory and practice of labor management, there are examples of successful application of innovative tools aimed at optimizing transaction costs. Nevertheless, according to the authors, the frequent problems of implementing the tools of lean production in the practices of Russian companies are related primarily to the distortion of the essence of these principles, with the formalism and instrumental attitude of the implementers, as well as with the lack of an innovation management system.

Keywords: lean production, kaizen, innovative model of corporate development, scientific management of labor, system of performance indicators.

\section{Introduction}

In the Soviet Union, the process of improving labor management based on achievements of science and best practices was defined by the term "scientific management of labor", which today is generally understood as improvement of organizational forms of the use of human labor in a particular work collective. In the USSR, one of the first theorists of the science of organization was A.A. Bogdanov, the author of the study "Tectology. The Overall Organizational Science" [Bogdanov, 1922]. Publications by Professor O.A. Ermansky, in particular, of the book The Taylor's System, The Scientific Management of Labor and Production, and the Taylor's System [Ermansky 1925] are of great interest. The problem of the scientific management of labor appears to them as "a rare combination of strong theoretical interest and the practical value of an urgent problem". The most significant contribution to the development of the scientific management of labor and production was made by A.K. Gastev. Scientific ideas and beliefs of A.K. Gastev were implemented in the work of the Central Institute of Labor.

The self-isolated and developing actively in the 1960-70s in the USSR scientific management of administrative work (SMAW) was dedicated to summarize the practical information, develop the theory and methodology of the rationalization and improvement of work processes of managers and specialists [Bogdanov, 1922].

Even at that time, there already were critical publications, the authors of which emphasized the insufficient research efforts in this field against the background of good intentions and high expectations from SMAW. V.I. Remnev wrote "Unfortunately, the activity for rationalizing the management apparatus based on scientific approach is understood sometimes only as the sum of efforts that can be reduced to the best furniture arrangement, ordering the document flow, and implementation of new equipment. This view of SMAW is unduly narrow. You cannot develop relatively minor problems and forget about the large-scale and fundamental elements of management; although, it would be wrong to get involved in global issues only and forget about details and particulars. Both of them are important. Understanding SMAW as a system of minor organizational efforts held at the lower levels is nothing but a "late welcome", reducing it to a "home trade" [Remnev, 1973, pp: 7-12]. Even then, some researchers insisted on systemic approach to elucidating the properties and relationships of rationalization objects, although in those circumstances it was, first of all, related to the interaction of public administration bodies and socialist enterprises. Later, in 1970s-1980s, SMAW narrowed to records keeping issues [Livshits, 1974]. The complexity and importance of the modern labor management, which also involves parallelism (simultaneity) of the flow of several labor operations, currently requires experts and practitioners to engage 
the entire set of tools and knowledge of the management theory and practice. Obviously, the rich heritage of the scientific management of labor in Russia may be involved in addressing such problems.

\section{Analysis of the Current Practice}

Today, most of the progressive approaches to labor management are combined within the framework of the general concept of lean production. It is believed that lean production is not an independent concept [Erokhin, 2009]. It had been developing gradually, over many years, and was a natural result of the accumulation of experience in organizational innovations at the Toyota Company. In the early and mid-1980s, there were publications and writings that described the Toyota Production System (TPS) [Shingo, 2010], and programs of studying the principles of TPS were launched in several universities. Generalizing the experience of Toyota, John Krafcik [Krafcik, 1988] introduced the term «lean» (fast, antonym - wasteful). Two main criteria characterizing the system of lean production at that time were supply of resources sharp on time and autonomation.

In Russia, hundreds of companies have declared that they will reform the management of their production systems based on the lean production principles. They include JSC AVTOVAZ, JSC Russian Aluminum, JSC UAZ, JSC Severstal, JSC SIBUR Holding, JSC Uralmashzavod, JSC VSMPO-AVISMA Corporation, enterprises of the GAZ group, and others. The financial institutions are represented by OJSC Sberbank of Russia, JSC Vneshtorgbank [Order No. 898, 2010].

In the Republic of Tatarstan, the lean production principles have been implemented to some extent and continue being implemented at JSC KAMAZ, JSC "Production Association "Elabuga Vehicle Plant"'", the Federal State Unitary Enterprise "Production Association "Sergo Plant", JSC "S.P. Gorbunov Kazan Aviation Production Association", JSC Spartak, JSC Kazankompressormash, JSC SOLLERS-Elabuga, JSC Kvart, JSC Nizhnekamskshina, JSC Kazan Helicopter Plant, JSC Almetyevsk Pipe Plant, JSC Vakuummash, JSC Tatneft, and others.

Having appeared in the late 1990s, the term "lean thinking" has recently become actively used in relation to intellectual work [James, Womack, and Daniel, 1996]. Use of this approach in the management of intellectual labor is acknowledged possible in case of [Matthew, 2011]:

- anthropocentric basis of transformations;

- admitting information as the basis of the price of intellectual labor. Therefore, information should be produced by the right person in the right form at the right time at the lowest price.

\section{Task Statement}

Can the principles and tools of lean production be successfully implemented in a Russian company? How can it be done in large corporations? If these questions are answered, the effect of implementation of this idea from the standpoint of reducing the time costs and other resources' consumption, avoiding duplication of costs, ensuring wide availability and continuous heredity of knowledge, etc. can be very strong.

\section{Methodology}

Currently, the concept of "lean production" is used by companies in many countries and in different sectors [Efimov, 2011]. The concept assumes that all activities of a company can be classified as follows: operations and processes that add value for the consumer, and the operations and processes that do not add the value. Thus, anything not adding value for the consumer is qualified by lean production as the loss, and should be eliminated [Maskell and Baggaley, 2010].

The model of innovative development of JSC Tatneft is based on the lean production concept and its technologies. It mainly refers to the integrated model, to be exact - it is at an intermediate stage of transition from the G4 to G5 model [Rothwell, 1994]. The innovation process is of network nature for units of a company [Yudina, 2008]; however, for the whole company it is of parallel nature. We can distinguish the following characteristic features of this model:

- integration of R\&D with production;

- cooperation with suppliers and buyers;

- horizontal cooperation;

- the practice of establishing cross-functional work groups;

- $\quad$ existence of an extensive feedback system;

- $\quad$ active implementation and use of information systems and technologies.

Formation of the innovative capacity is related to the internal and external environment [Ashirova, Garifullina, Serikova, and Yudina, 2014]. At the same time, the conditions of formation of an innovative model are more related to the 
factors of the internal environment, and the external environment provides the conditions for its implementation. With a view to the formation and development of innovative models the company implements methods and tools of lean production, formalizes and standardizes the innovation process, as well as familiarizes its employees with the innovative activity, and appropriately motivates them. All this is aimed at human capacity development, implementation and development of information systems and IT technologies, as well as development of the corporate culture of JSC Tatneft. The interaction of business units based on modern IT technology on a real-time basis at the premises of the Electronic Corporate University $(E C U)$, the Auction of Business Ideas ( $A B I)$, the Center of Excellence (CoE), allows implementing the innovative capacity and transform it into the innovation capital. For example, the combination of human capital and information technologies and systems lead to greater efficiency of the production (liquidation of losses, improvement of the efficiency of oil production, etc.) by detecting the actual production problems of the company and their optimal solution. This ultimately has a positive influence on the change in the competitiveness of JSC Tatneft and further sustainable development of the company [].

To assess the level of implementation of lean production in the structural units and subsidiaries, JSC Tatneft has developed a system of indicators grouped into seven blocks. The indicators are calculated after the cycle of auditing all facilities of the joint stock company.

The first block of indicators includes the system indicators targeting reflection of the general trends of lean production implementation in the structural units and subsidiaries of JSC Tatneft. This group includes:

1. Presence of an action plan for the implementation of lean production (ILP1): if there is a plan and it is implemented on time, 1 point is given, and if there is not -0 points.

2. The share of specialists who are certified in tools and techniques of the lean production in the ECU system (ILP2). This indicator is calculated as the ratio of managers, specialists, clerks who have passed certification in the methods of lean production in the ECU system to the total number of managers, specialists, clerks. If the result is less than $10 \%, 0$ points is given; from $10 \%$ to $25 \%$ - 1 point; from $25 \%$ to $50 \%$ - 2 points; from $50 \%$ to $75 \%-3$ points; over $75 \%-4$ points.

3. The share of workers certified in tools and techniques of the lean production (ILP3). It is calculated as the ratio of the number of workers certified in tools and techniques of lean production to the total number of workers. If the result is less than $10 \%, 0$ points is given; from $10 \%$ to $20 \%$ - 1 point; from $20 \%$ to $30 \%-2$ points; from $30 \%$ to $50 \%-3$ points; from $50 \%$ to $80 \%-4$ points; over $80 \%-5$ points.

4. Availability of information boards with the results of the implementation of lean production in public places $\left(\mathrm{D}_{\llcorner\mathrm{P} 4}\right)$. If the boards are present and relevant information is published on them, 1 point is given; if no relevant information is on them -0 points.

The second block includes the indicators of implementation of the "5S Workplace Organization" tool. The 5S system is a system designed to create and maintain high quality and comprehensive working environment in structural units and subsidiaries of JSC Tatneft, and is aimed at increasing the labor productivity and quality of its results, creating safe working environment. It is based on the five stages of workplace arrangement (sorting, keeping in order, keeping clean, standardization, improvement) [Fabrizio and Tapping, 2008]. This group includes six indicators characterizing it:

1. Presence of the section in the action plan for the implementation of the "5S Workplace Organization" tool (D5s1). If there is a developed plan and it is implemented on time, 1 point is given, and if there is not -0 points.

2. Application of the visualization method (contouring, marking, the method of road signs, "What was then" "What is now", visualized work instructions, color markings) (D5s2). This indicator is calculated as the ratio of the number of workplaces, which apply the visualization method, to the total number of workplaces. If the result is less than $25 \%$ - 0 points is given; from $25 \%$ to $65 \%$ - 1 point; more than $65 \%-2$ points.

3. The share of workplaces of workers standardized under the $5 \mathrm{~S}$ system (upon which four stages of the $5 \mathrm{~S}$ system have been implemented) (15s3). This indicator is calculated as the ratio of the number of workplaces of workers, upon which the four stages of the 5S system have been implemented, to the total number of workers' workplaces. If the result is less than $10 \%, 0$ points is given; from $10 \%$ to $25 \%-1$ point; from $25 \%$ to $40 \%-2$ points; from $40 \%$ to $60 \%-3$ points; from $60 \%$ to $80 \%$ - 4 points; over $80 \%-5$ points.

4. The share of workplaces of managers, specialists, clerks, standardized under the $5 \mathrm{~S}$ system (four stages of the $5 \mathrm{~S}$ system have been implemented) (I5s4). This indicator is calculated as the ratio of the number of workplaces of managers, specialists, clerks, upon which the four stages of the $5 \mathrm{~S}$ system have been implemented, to the total number of workplaces of managers, specialists, clerks. If the result is less than $10 \%$, 0 points is given; from $10 \%$ to $20 \%-1$ point; from $20 \%$ to $30 \%$ - 2 points; from $30 \%$ to $45 \%-3$ points; from $45 \%$ to $60 \%-4$ points; over $60 \%-5$ points.

5. The share of workplaces, upon which the fifth stage of the 5S system ("Improvement") is being implemented 
(D5s5). This indicator is calculated as the ratio of the number of workplaces, upon which the fifth stage of the $5 S$ system is being implemented, to the total number of workplaces. If the result is less than $10 \%, 0$ points is given; from $10 \%$ to $20 \%$ - 1 point; from $20 \%$ to $30 \%$ - 2 points; from $30 \%$ to $60 \%-3$ points; over $60 \%-4$ points.

6. Conducting the internal audit of compliance with the 5S System (D5S6). This indicator is intended to determine whether there is internal audit in the structural units and subsidiaries of JCS Tatneft, or there is not. If there is a developed and implemented internal audit, 1 point is given, and if there is not -0 points.

The third block includes the indicators of implementation of the "Total Productive Maintenance (TPM)" tool. The TPM system is aimed at maximizing the efficiency of the equipment operation throughout its life cycle, as well as encouraging people to participate in the production self-service [Marchwinski and Shook, 2005] in the structural units and subsidiaries of JSC Tatneft. This group includes the following indicators:

1. Availability in the action plan of the section for implementation of the "Total Productive Maintenance (TPM)" tool (ITPMI). If there is a developed plan and it is implemented on time, 1 point is given, and if there is not -0 points.

2. The share of key equipment, for which TPM standards have been developed (ITPM2). We need to note that key equipment includes equipment, which is directly engaged in the production of the final product. This indicator is calculated as the ratio of the number of units of the key equipment, for which TPM standards have been developed, to the total number of units of key equipment. If the result is less than $10 \%-0$ points is given; from $10 \%$ to $50 \%-3$ points; more than $50 \%-4$ points.

The fourth block of indicators assesses the completeness of implementation of the "Value Stream Mapping" tool. Mapping the value stream is aimed at creating a simple and intuitive graphical diagram showing the material and information flows needed to provide the end consumer with a product or service [Rother and Shook, 2005]. The map of the value stream allows immediately seeing the problems of the flow and, based on its analysis, identifying all wasteful expenditures and processes, and on this basis developing an improvement plan. The group includes the following indicators:

1. Presence of the section in the action plan for implementation of the "Value Stream Mapping" tool (Dvsm1). If this section is present and implemented on time, 1 point is given, and if it is not -0 points.

2. The share of units, in which value stream mapping is applied (IVsm2). This indicator is calculated as the ratio of units, in which value stream mapping is applied, to the total number of units. If the result is less than $10 \%-0$ points is given; from $10 \%$ to $50 \%-3$ points; more than $50 \%$ - 5 points.

3. Application of methods of searching for the root cause of the problem (using the Ishikawa or Pareto diagrams, the method of "five why", etc.) (Dvsm3). If at least one of the methods of searching for the root cause of the problem is used, 1 point is given, if none is used -0 points.

4. Presence of an action plan for achieving the "target" state of flows (Dvsm4). If there is a developed plan, and it is implemented on time, 1 point is given, and if there is not -0 points.

5. The estimated economic benefit at achievement of the desired stream condition (IvSM5). This index is assessed differentially so that the maximum value is 3 points, and the rest are assessed proportionally to the maximum value.

The fifth block of indicators is aimed at assessing the implementation of the "Training Within Industry (TWI)" and "Standardized Work" tools. The TWI training program is aimed at accelerated training of highly qualified workforce, saving manufacturing know-hows and experience of generations in the corporate knowledge base [Deming, 2007]. The "Standardized Work" tool is aimed at developing standard operations performance tables; drafting process flow sheet for standard operations; developing charts of standard operations, etc. This group includes three indicators:

1. The share of workplaces of workers equipped with process charts (Itw11). This indicator is calculated as the ratio of the number of workplaces of workers, for whom the standards of workplaces according to the $5 \mathrm{~S}$ system have been developed, to the total number of workplaces in an office. If the result is less than $10 \%, 0$ points is given; from $10 \%$ to $20 \%$ - 1 point; from $20 \%$ to $30 \%$ - 2 points; from $30 \%$ to $45 \%-3$ points; from $45 \%$ to $60 \%-4$ points; over $60 \%-5$ points.

2. Availability of multimedia training materials (lTw12). This indicator targets identifying availability of multimedia training programs, courses, etc. If they are present, 1 point is given, and if there are none of them -0 points.

3. Assigning mentors to newly adopted workers $\left(I_{T W} / 3\right)$. If the condition of the indicator of securing a mentor for newcomers is met, 2 points are given; in case this indicator is not met -0 points.

The sixth indicator - implementation of other tools and techniques of lean production (DıLP). This indicator assesses the development and implementation by structural units and subsidiaries of JSC Tatneft of tools and techniques 
of lean production, not listed in the previous groups of indicators, such as KANBAN, Single Minute Exchange of Dies (SMED), alignment, etc. If they have been implemented and are present, 1 point is given; if such methods and tools are not introduced -0 points.

The seventh block assesses the staff development and involvement in the innovative activity. These indicators are aimed at determining the activeness of employees, as well as on the analysis of the innovative capacity of human resources. In this group, the following three indicators, on which it is based, are singled out:

1. The number of filed kaizen proposals per employee $\left(\mathrm{I}_{\mathrm{KP} 1}\right)$. This indicator is calculated as the ratio of the total number of kaizen proposals filed for a certain period, to the number of employees. The maximum value of the indicator is 3 points, and the remaining are assessed in proportion to the maximum value.

2. The share of implemented kaizen proposals (IKP2). The indicator is calculated as the ratio of implemented kaizen proposals to the submitted ones. If the indicator reaches $80 \%$ or more, 3 points are given; if this value is not achieved -0 points.

3. Availability of information boards on lean production in public places $\left(D_{B P P}\right)$. This indicator is one of the indicators assessing the activeness of involving employees in the innovative activity. If there are boards on lean production, 1 point is given, and if there are none of them -0 points.

\section{Results}

Thus, all the seven blocks of assessment may be combined into the audit system (Table 1).

Table 1 - The system of audit of the level of implementation of the principles and tools of lean production in structural divisions of JSC Tatneft

\begin{tabular}{|c|l|c|c|}
\hline Sq. No. & Indicator description & Number of indicators & Maximum score \\
\hline \multicolumn{2}{|c|}{ Application of lean production methods } & 23 & 61 \\
\hline 1 & System indicators & 4 & 10 \\
\hline 2 & Implementation of the 5S workplace organization system & 6 & 19 \\
\hline 3 & Implementation of the TPM system & 2 & 5 \\
\hline 4 & Implementation of the Value Stream Mapping method & 3 & 11 \\
\hline 5 & $\begin{array}{l}\text { Implementation of the Training Within Industry (TWI), Standardized Work } \\
\text { methodologies. }\end{array}$ & 3 & 8 \\
\hline 6 & Implementation of other instruments of lean production (KANBAN, SMED, etc.). & 1 & 1 \\
\hline 7 & Staff development, involvement in innovative activities & 2 & 7 \\
\hline
\end{tabular}

The developed audit criteria were tested on real objects - the OGPDs of JSC Tatneft. The level values provided in Table 2 are valid, i.e. obtained by calculating the actual performance indicators at the facilities. But the used OGPD names are symbolic due to the confidentiality of information for external users.

Table 2 - Results of auditing the implementation of the lean production system at OGPDs of JSC Tatneft (as of 10.03.2014)

\begin{tabular}{|c|c|c|c|c|c|}
\hline \multirow{2}{*}{ Sq. No. } & \multirow{2}{*}{ OGPD } & \multicolumn{2}{|c|}{ Level of implementation of lean production tools } & \multicolumn{2}{c|}{ Target level (as of 01.07.2014) } \\
\cline { 3 - 6 } & & Actual level, score & $\%$ of MAX & Score & $\%$ \\
\hline 1 & OGPD-1 & 12 & 19.67 & 30.5 & 50 \\
\hline 2 & OGPD-2 & 21 & 34.43 & 30.5 & 50 \\
\hline 3 & OGPD-3 & 13 & 21.31 & 30.5 & 50 \\
\hline 4 & OGPD-4 & 9 & 14.75 & 30.5 & 50 \\
\hline 5 & OGPD-5 & 13 & 21.31 & 30.5 & 50 \\
\hline 6 & OGPD-6 & 20 & 32.79 & 30.5 & 50 \\
\hline 7 & OGPD-7 & 13 & 21.31 & 30.5 & 50 \\
\hline 8 & OGPD-8 & 5 & 8.20 & 30.5 & 50 \\
\hline 9 & OGPD-9 & 9 & 14.75 & 30.5 & 50 \\
\hline & OGPDs average & 12.8 & 20.95 & 30.5 & 50 \\
\hline
\end{tabular}




\section{Discussion}

Table 2 shows us that as of 10.03.2014, the average rate of implementation of the lean production system at OGPDs of JSC Tatneft is equal to 12.8 points on a 61-point scale, which corresponds to $20.95 \%$. The most active elements and techniques of lean production are implemented at OGPD-2, which scored 21 points (or 34.43\%) and OGPD-6 - 20 points (or 32.79\%). However, it should be noted that as of 07.01.2014, the indicators of these OGPDs had not yet reached the target level of 30.5 points (or 50\%). Kind of outsiders in the process of implementing the system of lean production are OGPD-8, which has the lowest rate -5 points (or 8.20\%), OGPD-4 and OGPD-9, the audit of which resulted in 9 points for each of them (or $14.75 \%$ ). Thus, the audit showed that the level of implementation of lean production at OGPD of JSC Tatneft is insufficient. That can speak volumes: of relative inactivity at lean production implementation, formal approach to implementation, as well as existing difficulties in providing conditions for lean production implementation in structural divisions of JSC Tatneft.

\section{Conclusion}

This guideline is rather simple and reflects the level of implementation of lean production in divisions of JSC Tatneft. During the implementation stage, this approach is rational and can objectively reflect the level of response of the controlled system to administrative influence. But at the same time, the guideline primarily reflects the organizational aspects related to providing conditions for implementation of the tools and technologies of lean production. At that, it ignores issues related to understanding the causes of the lean production implementation. The productivity of this organizational innovation, in our opinion, should be assessed by the value of liquidated wasteful expenditure of resources.

Thus, the study showed that implementation of the principles and tools of lean production is possible even in large Russian companies, and, implementation time can be quite acceptable. But the efficiency of introduction of this innovation is hard to evaluate due to the fact that in large organizational systems there is a high level of risk of substitution of the assessment of implicit, complex for measuring parameters with the explicit ones, but which are not essential and do not reflect the main effects.

\section{Acknowledgement}

We express our deep gratitude to the management of JSC Tatneft for the opportunity to study the experience of the company. Our special thanks to the Deputy Chief of the Labor Management and Wages Department of Tatneft Vladimir Petrovich Shumskikh.

\section{References}

Bogdanov, A.A. (1922). Tectology. Universal organizational science (In 3 parts). Berlin, Saint Petersburg, Moscow: Z.I. Grzhebin Publishing House.

Ermansky, O.A. (1922). Scientific organization of labor and the Taylor system (4th ed.) Moscow: Gosizdat.

Remnev, V.I. (1973). Scientific organization of administrative work. Pravovedeniye, 3.

Livshits Ya.Z., \& Tsikulin, V.A. (Eds.) (1974). Records management history in the USSR. Guide. Moscow: MSIHA.

Erokhin, E.A. (2009). Basic principles and components of the concept of lean production.

EKportal.ru. Retrieved 30.12.2012, from http://www. ekportal.ru/page-id-1114.html

Shingo, Sh. (2010). The study of the Toyota production system from an industrial engineering viewpoint. Moscow: Institute for Complex Strategic Studies.

Krafcik, J. (1988). Triumph of the Lean Production System. Sloan Management Review, October.

Decree of the Cabinet of Ministers of the Republic of Tatarstan "On approval of the concept of the target program "Implementation of the Lean Production project" in the Republic of Tatarstan in 2011-2013" of 12.11.2010 \#898.

Womack, J.P. \& Jones, D.T. (1996). Lean Thinking: Banish Waste and Create Wealth in your Corporation. Simon \& Schuster.

May, M. (2005). Lean Thinking for Knowledge Work. Retrieved 20.11.2011, from http://matthewemay.com/wp-content/uploads/2011/ 10/leanknowledge.pdf

Efimov, V.V. (2011). Fundamentals of lean production: a tutorial. Ulyanovsk: UISTU.

Maskell, B. \& Baggaley, B. (2010). Practical Lean Accounting: Practical lean accounting: a proven system for measuring and managing the lean enterprise. Moscow: Institute for Complex Strategic Studies.

Rothwell, R. (1994). Towards the fifth-generation innovation process. International Marketing Review, Vol. 11, 1.

Yudina, E.V. (2008). Modern forms of the innovation process organization. Herald of the Samara State University of Economics, 11(49). 
Ashirova, S., Garifullina M., Serikova N., \& Yudina S. (2014). Knowledge work management system in a corporation. Life Science Journal, 11(46).

Social statements of JSC Tatneft. Retrieved 17.07.2014, from http://www.tatneft.ru/sotsialnaya-politika/sotsialnaya-otchetnost/?lang=ru Fabrizio, Th., \& Tapping, D. (2008). Hoshin Kanri for the Lean Enterprise: Developing Competitive Capabilities and Managing Profit. Moscow: Institute for Complex Strategic Studies.

Marchwinski, C., \& Shook, D. (2005). Lean Lexicon. A Graphical Glossary for Lean Thinkers. Moscow: Alpina Business Books.

Rother, M. \& Shook, J. (2005). Learning to see: Value stream mapping to create value and eliminate muda. Moscow: Alpina Business Books.

Deming, E. (2007). Out of the crisis. The new paradigm of managing people, systems, and processes. Moscow: Alpina Business Books. 